УДК $94: 327.7(73+597)$ «1990-2000»

DOI: 10.26693/ahpsxxi2019.01.072

\title{
НОРМАЛІЗАЦІЯ І РОЗВИТОК АМЕРИКАНСЬКО-В'ЄТНАМСЬКИХ ВІДНОСИН У 1990-ті рр.
}

\author{
Наталія Городня, \\ e-mail:ngor@ukr.net \\ ORCID: https://orcid.org/oooo-ooo1-8152-3927 \\ Київський національний університет імені Тараса Шевченка, \\ Украӥна, о1о33, м. Київ, вул. Володимирсъка, $6 о$ \\ Інна Підберезних, \\ e-mail: innaevgenievna2017@gmail.com \\ ORCID: https://orcid.org/oooo-ooo1-9906-4327 \\ Чорноморсъкий національний університет імені Петра Могили, \\ Украӥна, 540оо, м. Миколаїв, вул. 68 Десантників, 10
}

У статті висвітлено процес нормалізацї і розвитку американсъко-в'єтнамсъких відносин за адміністрацій Дж. Г. У. Буша і Б. Клінтона, чинники, які на нъого впливали, основні подї і сфери двостороннъого співробітництва 1995-20оо рр. Показано, що підгрунтя для нормалізацї відносин між США і В’етнамом заклало ӥхне співробітництво у справі пошуку військовослужбовців США, які зникли під час В'єтнамсъкої війни. Після встановлення дипломатичних відносин у липні 1995 р. найбільш важливою подією було підписання у липні $20 о о$ р. Двостороннъої торговельної угоди, реалізація якої мала суттєвий вплив на позитивний розвиток двосторонніх відносин у XXI cm. Візит президента Б. Клінтона до В'єтнаму в листопаді $20 о о$ р. підвів підсумки цъого установчого періоду, основним змістом якого було звільнення політики двох держав від негативного спадку В'єтнамсъкої війни.

Ключові слова: американсъко-в'єтнамсъкі відносини, зовнішня політика США, зовнішня політика В’єтнаму, адміністрація Дж. Г. У. Буша, адміністрація Б. Клінтона

У 2020 році США та В’єтнам відзначатимуть 25-річчя встановлення дипломатичних відносин. Незважаючи на те, що у роки «холодної війни» вони були ворогами, більше того, у 1964-1973 рр. США воювали у В’єтнамі, після нормалізації їхні відносини набули позитивного спрямування й у 2013 р. досягли рівня «усебічного партнерства». Дослідження процесу нормалізації і розвитку відносин США і В’єтнаму у 1990-ті рр. створює підгрунтя для кращого розуміння напрямків і динаміки їхнього співробітництва в XXI ст., змін у зовнішній політиці цих держав, а також у регіональній ситуації у Східній Азії в перше постбіполярне десятиліття.

Окремі аспекти розвитку американсько-в’єтнамських відносин були висвітлені у працях I. Підберезних ${ }^{1}$ і Н. Городньої․ Проте ця тема не була предметом спеціального дослідження українських вчених.

У США існує велика наукова література, яка розкриває процес нормалізації відносин з В’єтнамом і чинників, які на нього впливали. Найбільшою мірою висвітлена

\footnotetext{
1 Підберезних, I.Є. (2012). Розвиток відносин між США і В’єтнамом: сучасний стан, напрямки, перспективи. Наукові праці історичного факультету Запорізького національного універсиmemy, XXXIV, 242-247.

${ }^{2}$ Городня, Н.Д. (2014). Східна Азія у зовнішній політиці США (1989-2013 рр.). Київ: Прінтсервіс.
} 
проблема в'язнів В’єтнамської війни і тих, хто зник без вісти під час бойових дій (POW/MIA). Ці дослідження систематизовано у праці Натана Р. Класона, який також проаналізував різні підходи у США до нормалізації відносин з В'єтнамом3. Передумови нормалізації американсько-в’єтнамських відносин висвітлено у працях Фредеріка Брауна з акцентом на змінах у міжнародній ситуації, які привели до «визрівання» позитивного вирішення цього питання4. Започаткування американськов’єтнамських контактів у сфері безпеки і оборони описано у працях К. Тайера, С. Старра5, У. Ломана, Д. Стерна й У. Джордана6.

Розвиток американсько-в’єтнамських відносин досліджують співробітники аналітичних центрів США й інших держав Азійсько-Тихоокеанського регіону з акцентом на сучасному стані цих відносин у різних сферах з метою вироблення політичних рекомендацій щодо бажаних напрямів їхнього подальшого розвитку7. Хоч такі аналітичні розвідки супроводжуються історичним оглядом, він має обмежений характер і розкриває лише окремі аспекти цієї проблематики, що обумовлено цілями цих політологічних досліджень.

Метою цієї статті є висвітлення процесу нормалізації американсько-в’єтнамських відносин продовж першого постбіполярного десятиліття за адміністрацій Дж. Г. У. Буша і Б. Клінтона, виявлення чинників, які на нього впливали, а також визначення основних подій і процесів у двосторонніх відносинах після нормалізації за президентства Б. Клінтона,

В основі методології дослідження - вивчення і критичний аналіз історичних джерел і наукової літератури, застосування проблемно-хронологічного і компаративного підходів. Розвиток двосторонніх відносин між США і В’єтнамом розглядається на тлі змін у зовнішній політиці цих держав і регіональної ситуації у Східній Азії.

Історичні джерела для дослідження цієї проблематики можна поділити на кілька груп: 1) двосторонні і міжнародні угоди за участю США і В'єтнаму; 2) Стратегії національної безпеки США; 3) промови, інтерв’ю, праці президентів, держсекретарів, послів та інших посадових осіб США і В’єтнаму; 4) доповіді і слухання комітетів Конгресу США стосовно В'єтнаму; 5) матеріали Держдепартаменту США і Міністерства закордонних справ В’єтнаму, Посольств В’єтнаму в США і США у В'єтнамі; 6) інформація 3МІ. Також автори посилаються на результати попередніх досліджень науковців з проблематики, що вивчається.

США і Соціалістична Республіка В’єтнам (СРВ) встановили дипломатичні відносини 12 липня 1995 р. за першої адміністрації Б. Клінтона. Передумовами для цього були: по-перше, співробітництво В'єтнаму з США у справі пошуку американських військовослужбовців - в'язнів війни і тих, хто пропав без вісти під час військових дій (POW/MIA); по-друге, початок у 1986 р. економічних ринкових реформ у В'єтнамі («політика оновлення», Doi Moi); по-третє, закінчення інтервенції В'єтнаму в Камбоджі (1978-1989 рр.) й урегулювання камбоджійської проблеми; по-четверте, завершення «холодної війни» і розпад СРСР, що призвело до втрати В’єтнамом свого єдиного союзника.

3 Clason, N.R. (2017). Two Sides on «Normal»: A Comparison of Eight Views on U.S. Rapprochement with Vietnam, 1989-1995. Retrieved from https://d.lib.msu.edu/etd/4593

4 Brown, F.Z. (2010, December). Rapprochement between Vietnam and the United States. Contemporary Southeast Asia, 32 (3), 317-342. Retrieved from https://www.jstor.org/stable/25798860

5 Thayer, C.A. \& Starr, C.V. (2005). The Prospects for Strategic Dialogue. Dialogue on U.S.-Vietnam Relations. Ten Years after Normalization, 3. San Francisco: The Asia Foundation. Retrieved from https://asiafoundation.org/resources/pdfs/1-VN10YearsAfterNormalization.pdf

${ }^{6}$ Lohman, W., Lewis, S. \& Colonel Jordan, W. (2012, July 18.). U.S.-Vietnam Defense Relations: Investing in Strategic Alignment. Retrieved from https://www.heritage.org/asia/report/us-vietnamdefense-relations-investing-strategic-alignment

7 Vuving, A. (2017, May 27). What Vietnam Can Offer America. The National Interest. Retrieved from https://nationalinterest.org/feature/what-vietnam-can-offer-america-20874?page=5; Shoji, T. (2018). Vietnam's Security Cooperation with the United States: Historical Background, Present and Future Outlook. Retrieved from http://www.nids.mod.go.jp/english/publication/kiyo/pdf/2018/bulletin_e2018_2.pdf 
За аналізом Н. Класона, за нормалізацію американсько-в’єтнамських відносин виступали п'ять груп акторів: чотири адміністрації США, від Д. Картера до Б. Клінтона, Сенатський комітет зі справ POW/MIA (1991-1993), сенатори Джон Маккейн і Джон Керрі, американський бізнес, а також Комуністична партія В'єтнаму. До акторів, які виступали проти нормалізації, він відносить передусім виконавчого директора Національної ліги сімей POW/MIA Енн Міллз Гріффітс і американців в’Єтнамського походження 3 адміністративного району (county) Оріндж, Каліфорнія, де проживало найбільше втікачів від комуністичного режиму8.

Після закінчення В'єтнамської війни залишалося багато американських військовослужбовців, які вважалися такими, що зникли без вісти. У їхніх родин зберігалися надії, що вони були живими, але не могли повернутися додому через утримання у в'язницях В'єтнаму. Так виникло питання в'язнів війни і тих, хто зник під час військових дій (POW/MIA). За адміністрації Дж. Картера було проведено низку розслідувань 3 цього питання. Тоді ж було здійснено першу спробу нормалізації відносин 3 В'єтнамом. У 1977-1978 рр. відбувалися переговори, проте вони не були успішними9. Натомість В'єтнам підписав економічні й безпекові угоди з СРСР, а в грудні 1978 р. здійснив інтервенцію в Камбоджу. У відповідь Китай здійснив наступ на північний кордон В'єтнаму. Нормалізація відносин між США і Китаєм у цей час сприяла подальшому зближенню між В'єтнамом і СРСР, що унеможливило нормалізацію американсько-в’єтнамських відносин.

За президентства Рональда Рейгана перші контакти між США і В'єтнамом відбулися лише в 1987-1988 pр. У серпні 1987 р. спеціальний представник Р. Рейгана генерал Джон Вессей вперше відвідав В'єтнам для обговорення гуманітарних питань взаємного інтересу, а саме POW/MIA й очищення території В'єтнаму від мін і «снарядів, які не вибухнули» (UXO). Його другий візит до В'єтнаму з цією метою відбувся у вересні 1988 р. У січні 1989 р. було підготовлено Фінальну доповідь адміністрації Рейгана з питання POW/MIA. У ній зазначалося, що припущення про утримання американців у В'єтнамі без їхньої згоди не були підтверджені. 3 кінця 1980-х pp. розпочався пошук решток загиблих американських військовослужбовців на території В'єтнаму за участю пошукових команд із СШАํ․

Президентство Дж. Г. У. Буша (1989-1993) співпало у часі із закінченням «холодної війни» і кризою, а врешті й розпадом, СРСР. В’єтнам опинився з міжнародної ізоляції і виявив більшу схильність до контактів з США. У вересні 1990 р. відбулася зустріч міністра закордонних справ В’єтнаму з держсекретарем Дж. Бейкером у Нью-Йорку, під час якої обговорювалося питання про співробітництво двох держав у справі пошуку американських військовослужбовців, які зникли під час В’єтнамської війни.

У квітні 1991 р. в Ханої було відкрито «польовий офіс» для розгляду цих справ. Це був перший офіційний пункт присутності США у В’єтнамі після закінчення війни. У Ханої відбулися дводенні переговори, після яких спеціальний посланець США генерал Джон Вессей заявив, що обидва уряди прагнули нормалізувати відносини, проте на перешкоді цьому стояли відмінності у поглядах на урегулювання камбоджійського питання. Тому цей офіс було відкрито на тимчасовій основі. Переговори 3 цього питання мали продовжуватися ${ }^{11}$.

9 квітня 1991 р. американський уряд оголосив «4-крокову дорожню карту» нормалізації відносин з В’єтнамом. Передумовами для встановлення дипломатичних

\footnotetext{
8 Clason, N.R. Op. cit., 2-3.

9 Brown, F. Z. Op.cit., 320.

${ }^{10}$ Clason, N.R. Op.cit., 2; Ministry of Foreign Affairs. (2010, June 29). Vietnam-US Ties Boosted by Trust Building Efforts. Retrieved from http://www.mofa.gov.vn/en/nro40807104143/ nr040807105001/ns100630150512/view; Albert, E. (2019, March 20). The Evolution of U.S.Vietnam Ties. Backgrounder. Retrieved from https://www.cfr.org/backgrounder/evolution-usvietnam-ties

${ }^{11}$ U.S. to Open an M.I.A. Office in Hanoi (1991, April 21). The New York Times. Retrieved from https://www.nytimes.com/1991/o4/21/world/us-to-open-an-mia-office-in-hanoi.html
} 
відносин визнавався подальший прогрес у камбоджійському мирному процесі і розширення співробітництва з розслідування справ POW/MIA ${ }^{12}$.

Після публікації кількох фото із зображенням ув’язнених у Південно-Східній Азії американців, у 1991 р. був створений тимчасовий комітет Сенату США для дослідження справ POW/MIA. До його складу, між інших, увійшли ветерани війни демократ Джон Керрі і республіканець Джон Маккейн, які виступали за нормалізацію відносин з В'єтнамом.

Важливою віхою на шляху реалізації «дорожньої карти» було підписання 23 жовтня 1991 р. Фінального акту Паризької конференції по Камбоджі, який завершив переговори, розпочаті в серпні 1989 р., і підтримка В’єтнамом плану камбоджійського урегулювання ${ }^{13}$.

Після цього у листопаді-грудні 1991 р. уряд США зняв обмеження на подорожі американців до В'єтнаму, дозволив американським компаніям відкривати там офіси і підписати деякі попередні контракти в очікуванні зняття торговельного ембарго 14. Його було запроваджено проти Північного В'єтнаму у 1964 р., а після об'єднання В’єтнаму під владою комуністів у квітні 1975 р. поширено на усю країну. У квітні 1992 р. було знято обмеження на телекомунікаційний зв'язок із В’єтнамом і дозволено в'єтнамським американцям пересилати гроші своїм родичам.

Проте за президентства Дж. Г. У. Буша зняття торговельного ембарго США з В'єтнаму не відбулося, як і встановлення дипломатичних відносин. За свідченням держсекретаря Дж. Бейкера, у цей час Східна Азія не була пріоритетом зовнішньої політики США 15. Центральною місією адміністрації Дж. Г.У. Буша у сфері зовнішньої політики було завершення «холодної війни» $\mathrm{i}$ «управління процесом руйнування комунізму»16. Доповідь зі стратегї національної безпеки 1990 р. називала основною стратегічною ареною Америки Європу17. Найбільш важливими проблемами зовнішньої політики США за адміністрації Буша врешті виявилися війна у Перській затоці, об'єднання Німеччини, відносини з СРСР і близькосхідний мирний процес. У Східній Азї̈ найбільшу увагу вона приділяла «порятунку проблемного шлюбу з Китаєм», «залученню» Північної Кореї, формуванню основ нової економічної дипломатії і відносинам з Японією ${ }^{18}$.

У січні 1993 р. спеціальний сенатський комітет опублікував звіт, у якому зазначалося, що немає свідчень про насильницьке утримання владою В'єтнаму колишніх в'язнів війни ${ }^{19}$. Цей звіт мав суттєвий вплив на прискорення процесу нормалізації двосторонніх відносин за наступної адміністрації Б. Клінтона.

У першій рік президентства Б. Клінтона (січень 1993 - січень 2001 рр.) відбулося відкриття офісів держдепартаменту США у Ханої і МЗС В’єтнаму у Вашингтоні. У квітні 1993 р. перша американська компанія (Vatico) відкрила офіс у В’єтнамі. У липні 1993 р. Б. Клінтон дав згоду на рефінансування Міжнародним валютним фондом іноземного боргу В’єтнаму (у розмірі 140 млн. дол.), що відкрило для нього можливості отримувати міжнародні кредити і фінансову допомогу. У вересні американські компанії отримали дозвіл брати участь у проектах з розвитку, профінансованим міжнародними інституціями.

12 U.S. to Open an M.I.A. Office in Hanoi (1991, April 21). The New York Times. Retrieved from https://www.nytimes.com/1991/04/21/world/us-to-open-an-mia-office-in-hanoi.html

13 The University of Edinburgh. Peace Agreements Database. Final Act of the Paris Conference on Cambodia. Retrieved from: https://www.peaceagreements.org/view/378

14 Embassy of the Socialist Republic of Vietnam in the United States of America. Timeline. Retrieved from http://vietnamembassy-usa.org/vietnam-us-relations/timeline

15 Baker, J.A. III \& Defrank, T.M. (1995). The Politics of Diplomacy. Revolution, War and Peace, 1989-1992. New York, 42-43.

16 Ibid, 45 .

${ }_{17}$ Historical Office. Office of the Secretary of Defense. (1990, March). The National Security Strategy of the United States. The White House, Washington D.C., 9. Retrieved from https://history.defense.gov/Portals/70/Documents/nss/nss1990.pdf?ver=2014-06-25-121138-080 18 Baker, J. A. III \& Defrank, T. M. Op. cit., 588, 604.

19 MIA Affairs United States Senate. (1993, January 13). Senate Report 103-1 POW / MIA'S Report of the Select Committee on POW. Retrieved from https://fas.org/irp/congress/1993_rpt/pow-exec.html 
У січні 1994 р. сенат проголосував (62-38) за зняття ембарго на торгівлю з В’єтнамом. Після підписання закону президентом, це відбулося у лютому 1994 р. Також у 1994 р. було відкрито програму Фулбрайта для викладачів економіки в Економічному університеті міста Хошимін (колишнього Сайгону)²0.

Дії американського уряду, спрямовані на нормалізацію відносин з В'єтнамом, викликали опозицію з боку Національної ліги сімей POW/MIA і деяких груп ветеранів. 3 метою зменшення їхнього спротиву для представників Ліги і лідерів ветеранських організацій було організовано поїздки до В’єтнаму в березні та липні 1994 р. Це не вплинуло на позицію Ліги, але ветеранські організації підтримали нормалізацію відносин, або, принаймні, не протестували проти цього ${ }^{21}$.

У грудні 1994 р. В'єтнам відвідала делегація Конгресу США. Вона мала багато зустрічей, включаючи генерального секретаря Компартії В'єтнаму До Миоя, міністра закордонних справ Нгуен Ман Кама, міністра торгівлі, міністра у справах MIA, представників Фундації в'єтнамських ветеранів Америки і Американської палати торгівлі, а також взяла участь у церемонії відкриття у Ханої офісу американської компанії виробника тракторів Катерпіллар. У звіті представників цієї делегації Ф. Мурковські й П. Саймона зазначався стрімкий економічний розвиток В'єтнаму і зростання присутності американського бізнесу в Ханої. Американські інвестиції у В’єтнамі в кінці 1994 р. склали 270 млн. дол., вкладені у 28 проектів. США стали 12-м найбільшим інвестором у В'єтнамі (для порівняння: у Тайвань, який посідав перше місце в інвестиціях США, американські компанії вклали 1,9 млрд. дол., в Японію - 783 млн. дол.).

Основною перешкодою для нормалізації двосторонніх відносин визначалася проблема MIA. На той час залишалися не ідентифікованими ще 2211 справ. Серед американців існувала думка, що повного розслідування справ зниклих військовослужбовців не відбулося. Проте спеціальна група міністерства оборони США, створена з цією метою, повідомляла про повне співробітництво в'єтнамців у цьому питанні. Аналогічної думки дотримувалися і члени делегації Конгресу. Серед проблем, які залишалися, вони називали обмеження свободи слова і порушення прав людини у B'єтнамі, особливо проти буддистів i, меншою мірою, католиків. Водночас зазначався деякий прогрес у другому питанні, порівняно з попереднім періодом²2.

Через місяць після цього візиту, у січні 1995 р. дві держави створили офіси зв'язку. Після цього зі спеціальними місіями до В'єтнаму кілька раз їздив заступник держсекретаря Р. Лорд.

11 липня 1995 р. Б. Клінтон оголосив рішення про встановлення дипломатичних відносин з В’єтнамом. За оцінкою держсекретаря У. Крістофера, це було одне з найбільш складних для нього рішень у сфері зовнішньої політики під час першої адміністрації 23.

Серед важливих мотивів нормалізації відносин США з В'єтнамом були економічні можливості у цій державі для американського бізнесу. Домінуючою темою внутрішньої і зовнішньої політики США 1990-х рр. було розширення експортних ринків для відновлення американської економіки і забезпечення робочих місць для американців. Велика увага у цьому контексті приділялася Східній Азіі. Значний потенціал B'єтнаму й урядова політика реформ створювали підстави прогнозувати його пере-

${ }^{20}$ Ministry of Foreign Affairs. (2007, November 29). US to Increase Scholarship Funds for Vietnam: US Ambassador. Retrieved from http://www.mofa.gov.vn/en/cn_vakv/america/ nro40819114015/ns071129092940/view

${ }^{21}$ Clason, N. R. Op.cit., 4.

22 United States. Congress. Senate. Committee on Foreign Relations. (1995). Congressional Delegation Trip Report: Countries Visited: Mongolia, People's Republic of China, North Korea, South Korea, and Vietnam, December 3-17, 1994: a report to the Committee on Foreign Relations, United States Senate by Frank H. Murkowski and Paul Simon. Washington: U.S. G.P.O., 13-15. Retrieved from https://babel.hathitrust.org/cgi/pt?id=pst.o00023494220\&view=1up\&seq=3

${ }_{23}$ Christopher, W. (1998). In the Stream of History: Shaping Foreign Policy for a New Era. Stanford, Calif.: Stanford University Press, 303. 
творення на чергового «азійського тигра», а 8о-мільйонного, переважно молодого, населення на споживачів. Як вважає Ф. Браун, без лобіювання Конгресу великими американськими корпораціями як Боїнг, Дженерел Електрік, Катерпіллар, Мікрософт, нормалізація й далі відкладалася через проблему POW/MIA і спротив організованих груп будь-яким поступкам В'єтнаму24.

За іншими оцінками, для США нормалізація відносин з В'єтнамом мала значення передусім через важливість В’єтнамської війни в їхній історії, потребу консолідації американського суспільства і психологічного здолання спадку війни. Як зазначав у своїй інаугураційній промові Дж. Г. У. Буш у січні 1989 р., «фінальні уроки В’єтнаму такі, що жодна велика нація не може довго витримати роз'єднання пам'яттю»25.

Як свідчить Реймонд Бургхард, посол США у В’єтнамі у 2001-2004 pp., на початку 1990-х рр. урядова політика США щодо нормалізації відносин з В'єтнамом рухалася інтересами кількох різних груп, не пов’язаних між собою. Це були сім'ї військовослужбовців, які прагнули повернути додому своїх рідних; ветерани, які шукали примирення; американці в'єтнамського походження, які хотіли об’єднатися зі своїми сім'ями; підприємці, які прагнули експортувати чи інвестувати у В'єтнам²6.

Для В’єтнаму нормалізація відносин з США, яка відбулася за уряду Во Ван Кієта, була важливою передусім з точки зору реалізації економічних реформ і переходу до нової моделі економічного розвитку. У 1990-ті рр. США були найбільшим експортним ринком світу, доступ до якого був важливим для розвитку економіки В'єтнаму. Також В’єтнам потребував підтримки США для отримання міжнародної допомоги на розвиток і кредитів міжнародних фінансових інституцій, а також для вступу до системи ГАТТ (з 1 січня 1995 р. - Світової організації торгівлі, СОT) і багатосторонніх організацій.

Крім США, у 1990-ті pp. В’єтнам здійснював нормалізацію відносин з іншими державами і намагався диверсифікувати зовнішні зв'язки, щоб уникнути залежності від однієї держави, як це було в минулому (від СРСР). Відносини з США були важливі для в’єтнамського уряду лише тією мірою, доки це не підривало існуючу однопартійну систему на чолі з Комуністичною партією.

Одним з чинників, які стримували розвиток двосторонніх відносин, була проблема прав людини. Національна стратегія безпеки США за президентства Б. Клінтона базувалася на концепції «розширення спільноти ринкових демократій» 27 , реалізація якої передбачала сприяння демократії і захист прав людини за кордоном. У зв’язку з цим політика США щодо В'єтнаму багато в чому визначалася ситуацією у сфері прав людини цій державі. Представники американського уряду постійно піднімали цю тему на переговорах. Питання про права людини у B'єтнамі, з акцентом на релігійних свободах, розглядалося на слуханнях у комітетах з міжнародних справ Конгресу США28. Така позиція США розцінювалася у В'єтнамі як втручання у його внутрішні справи. В'єтнамський уряд вважав, що «імперіалістичні сили» намагатимуться зруйнувати соціалістичний лад зсередини через «мирну еволюцію», шляхом просування «західних» цінностей демократії і прав людини.

24 Brown, F. Z. Op.cit., 322.

25 The Avalon Project. Documents in Law, History and Diplomacy. (1989, January 20). Inaugural Address of George Bush. Retrieved from https://avalon.law.yale.edu/2oth_century/bush.asp

${ }^{26}$ Burghardt, R.F. (2006). Old Enemies Become Friends: U.S. and Vietnam. Retrieved from https://www.brookings.edu/opinions/old-enemies-become-friends-u-s-and-vietnam/

27 Historical Office. Office of the Secretary of Defense. (1994, July). A National Security Strategy of Engagement and Enlargement. The White House, Washington D.C., ii, 2. Retrieved from https://history.defense.gov/Portals/70/Documents/nss/nss1994.pdf?ver=2014-06-25-121219-500 ${ }_{28}$ U.S. Congressman Chris Smith. (1996). Human Rights in Vietnam. Joint Hearing before the Subcommittees on Asia and the Pacific and International Operations and Human Rights of the Committee on International Relations House of Representatives. One Hundred Fourth Congress. First Session. November 8, 1995. Washington D. C.: U. S. Government Printing Office. Retrieved from https://chrissmith.house.gov/uploadedfiles/1995.11.08_human_rights_in_vietnam.pdf 
У липні-серпні 1995 р. держсекретар У. Крістофер здійснив десятиденний візит до Східної Азії, під час якого відвідав В’єтнам. Це був перший візит держсекретаря США до Ханоя. У вересні 1995 р. цю країну відвідав колишній президент Дж. Г. У. Буш ${ }^{29}$. У липні 1996 р. відбувся візит до Ханоя радника президента з національної безпеки Ентоні Лейка, під час якого були висловлені пропозиції щодо співробітництва США і B'єтнаму у сфері безпеки поза межами питання MIAзо.

У 1997 р. дві держави обмінялися послами. Першим послом США у В’єтнамі став Дуглас (Піт) Пітерсон, ветеран В’єтнамської війни, колишній POW, який провів у в’язниці Ханоя шість 3 половиною років (1966-1973рр.).

Невдовзі після відкриття посольства, у червні 1997 р. відбувся офіційний візит до Ханоя держсекретаря М. Олбрайт. Вона підписала угоду про захист прав інтелектуальної власності і оголосила про плани відкриття консульства США у місті Хошимін, що відбулося у листопаді того ж року. У своїх виступах вона закликала владу В'єтнаму послабити репресії, і зазначала, що «економічна й політична відкритість $\epsilon$ двома сторонами однієї монети... Обидві потрібні для розвитку, обидві залежать від створення життєздатного громадянського суспільства і поваги до влади закону»31.

У жовтні 1998 р. до Вашингтона прибув міністр закордонних справ В'єтнаму Нгуен Мань Кам. Це був перший офіційний візит представника в’єтнамського уряду до США. М. Олбрайт і Нгуен Мань Кам повторно обмінялися візитами у 1999 і 2000 рр.

У 1998 р. у США було прийнято закон про релігійну свободу, що посилило увагу американського уряду до її стану у В'єтнамі. У цьому ж році вперше було опубліковано «Білу книгу» В'єтнаму, у якій однією з основних цілей оборони визначалися попередження і зрив будь-якої діяльності, яка загрожує політичній і соціальній стабільності держави ${ }^{2}$.

Загалом у перші роки після встановлення дипломатичних відносин зв'язки між США і В'єтнамом у різних сферах розвивалися повільно. Вони інтенсифікувалися в кінці 1990-х рр. у торговельно-економічній сфері. Це відбулося під впливом Азійської фінансово-економічної кризи 1997-1999 рр., яка призвела до обвалу національних валют окремих держав Східної Азії і зруйнувала регіональні ринки. Для виходу з кризи вони суттєво збільшили свій експорт до США. Натомість, відбулося зменшення експорту США до Східної Азї̈, що мало негативний вплив на баланс торгівлі, а врешті й федерального бюджету США. У цих умовах адміністрація Б. Клінтона шукала можливостей для розширення експортних ринків, тож звернула більшу увагу на перспективи розвитку торгівлі з В'єтнамом, який відчув вплив кризи лише опосередковано. У той час як перша адміністрація Б. Клінтона робила ставку на багатосторонні торговельноекономічні домовленості у рамках форуму ATEC, під впливом кризи більшого значення набули двосторонні угоди про вільну торгівлю, у рамках яких було легше і швидше досягти бажаного результату - збільшення експортуз3. Для В'єтнаму негативний вплив кризи на сусідні азійські держави став поштовхом до прискорення і поглиблення економічних реформ, щоб уникнути такої кризи в майбутньому.

У березні 1998 р. президент Клінтон оголосив про скасування щодо В’єтнаму дії поправки Джексона-Веніка до Торговельного акту 1974 р., згідно 3 якою торгівля США з країнами, у яких порушувалися права людини, обумовлювалася певними вимогами. У січні 1999 р. в’єтнамський уряд гарантував «найбільш сприятливий статус» американським компаніям, які працювали в країні, хоча в цей час ще не існувало торговельної угоди між США і В’єтнамом.

${ }^{29}$ Shenon, P. (1995, August 5). Bush is Criticized for Plans to Speak in Vietnam. The New York Times. Retrieved from https://www.nytimes.com/1995/08/05/world/bush-is-criticized-for-plansto-speak-in-vietnam.html

30 Thayer, C.A. \& Starr, C.V. Op.cit., 27.

${ }^{31}$ AP Archive. (1997, June 27). Vietnam: Hanoi: US Secretary of State Madeleine Albright Visit. Retrieved from http://www.aparchive.com/metadata/youtube/c95f1a6c77433a915d659cdd773e86ba ${ }^{22}$ Shoji, T. Op.cit., 4-5.

33 Городня, Н.Д. Op.cit., 193-203, 225-228. 
До кінця 1990-х рр. було підписано кілька угод, які регламентували торговельноекономічні відносини між двома державами. Найбільш важливою серед них була Двостороння торговельна угода, підписана 13 липня 2000 р.34. Вона стала основним документом, який визначив позитивний напрям розвитку американськов’єтнамських відносин у наступні роки. За цією угодою зменшувалися тарифи на багато товарів, включаючи сільськогосподарську продукцію і електроніку, в середньому з 40 до 3\%, а також ліквідовувалося багато нетарифних торговельних бар'єрів, включаючи квоти, заборони, імпортні обмеження. Ханой мав здійснити заходи щодо подальшої лібералізації економіки, послабити бар'єри для імпорту послуг з США (у сфері банківських послуг і телекомунікації), гарантував захист прав інтелектуальної власності й іноземних інвестицій. США тимчасово поширили на В'єтнам «нормальні торговельні відносини», що створило необхідні передумови для переговорів про його вступ до СОТ, а це було однією з основних цілей в’єтнамського уряду. Оскільки цей договір був оснований на принципах COT, це полегшило подальші переговори В’єтнаму про вступ до цієї організації. За офіційними оцінками представників уряду В’єтнаму, ця угода мала суттєвий позитивний вплив на в’єтнамську економіку35.

Двостороння торговельна угода вступила в дію в кінці 2001 р. за наступної адміністрації Дж. У. Буша, після чого обсяги торгівлі між США і В’єтнамом різко зросли. Якщо у кінці 2001 р. двостороння торгівля складала 1,5 млрд. дол., то у 2005 р., через 10 років після нормалізації відносин, вона складала 7,8 млрд., тобто зросла у п’ять раз. У 2006 р. США стали для В’єтнаму найбільшим експортним ринком³6.

Крім торговельно-економічної сфери США і В’єтнам підписали кілька документів на рівні міністрів у сфері охорони здоров'я, розвитку трудових ресурсів і науки - Спільне комюніке про співробітництво у сфері охорони здоров’я (грудень 1997 р.), угоду про співробітництво у сфері спорту і фізичного тренування (березень 1999), меморандуми про порозуміння у сфері розвитку трудових ресурсів (листопад 2000) і метеорологічного і гідрологічного співробітництва (січень 2001).

Зі сферою медицини були тісно пов’язані гуманітарні проблеми, які залишилися 3 часу В'єтнамської війни. Найбільш важливою для В'єтнаму була проблема зменшення негативного впливу на навколишнє середовище і здоров'я людей отруйної речовини діоксин («агент Оранж»), яку розпиляла американська авіація під час війни, а також отримання компенсації для жертв отруєння.

Гуманітарні проблеми, пов'язані зі спадком війни (обмін інформацією, необхідною для пошуку MIA, спільні польові операції з пошуку загиблих, повернення їх на батьківщину, розмінування і знешкодження снарядів, які не вибухнули, а також зменшення негативних наслідків застосування «агенту Оранж») домінували також у двосторонніх відносинах у сфері безпеки ${ }^{37}$. Також в’єтнамські військові відвідували конференції й семінари, організовані Тихоокеанським командуванням США (РАСОМ), відбувалися військові обміни високого рівня.

Ці обміни включали, між іншим, візити до В’єтнаму делегації у складі посадовців Департаменту оборони, Держдепартаменту, Ради національної безпеки і Тихоокеанського командування на чолі із заступником помічника секретаря оборони Куртом Кемпбеллом у жовтні 1996 р., головнокомандувача тихоокеанського командування США (РАСОМ) Джозефа Прюхера у лютому 1997 р. і грудні 1998 р., делегації Департаменту оборони у березні 1998 р., а також візити до Вашингтона заступника міністра

34 U.S. Embassy and Consulate in Vietnam. Bilateral Trade Agreement. Retrieved from https://vn.usembassy.gov/our-relationship/policy-history/bilateral-trade-agreement/ 35 Ministry of Foreign Affairs. (2005, June 23). Trade Agreement with the US is Good Beginning to Vietnam's WTO Bid. Retrieved from http://www.mofa.gov.vn/en/nro40807104143/ nro40807105001/nso50621101212/view

${ }^{36}$ Ministry of Foreign Affairs. (2019, June 13). Viet Nam-U.S. Relations. Retrieved from http://www.mofa.gov.vn/en/cn_vakv/america/nro40819114015/nso71015155903

37 Ministry of Foreign Affairs. (2007, July 2). Vietnam-US Relations Outlook. Retrieved from http://www.mofa.gov.vn/en/cn_vakv/america/nro40819114015/ns041111092523/view 
національної оборони В’єтнаму генерала Тран Ханя у лютому 1997 р. і жовтні 1998 р. Під час офіційного візиту до США міністра закордонних справ Нгуен Мань Кама у жовтні 1998 р. він також відвідував Пентагон ${ }^{3}$. На цих зустрічах обговорювалися питання, які виходили за межі МIA. Американська сторона пропонувала розширити формат співробітництва, включаючи спільні двосторонні і багатосторонні навчання, а також візити кораблів ВМФ США до в’єтнамських портів.

Кульмінацією цих контактів був перший візит до В'єтнаму міністра оборони США У. Коена у березні 2000 р. Крім традиційних питань - пошуку решток військовослужбовців США - У. Коен виступив з пропозиціями про співробітництво у таких сферах як видалення наземних мін, пошук і порятунок, ліквідація наслідків природних лих, включаючи контроль над повенями, спільні медичні дослідження, включаючи «Агент Оранж», посилення діалогу з проблем регіональної безпеки. Він також запропонував розширити військове співробітництво шляхом дозволу візитів військових кораблів США у порти В’єтнаму.

Після візиту У. Коена співробітництво військових поширилося на три основні сфери: допомога у розмінуванні і вилученні снарядів, які не вибухнули; гуманітарна допомога при повенях; двостороннє співробітництво у військовій медициніз9. У червні 2000 р. США пообіцяли виділити 1,7 млн. дол., щоб допомогти В’єтнаму знищити міни і снаряди, які залишилися з часу війни ${ }^{40}$. Також розпочалися технічні переговори з питань портових візитів 41 . Хоча посол Піт Пітерсон прогнозував, що перший корабель ВМФ США увійде у в’єтнамський порт продовж року, це відбулося лише у листопаді 2003 р. Тоді ж відбувся перший візит міністра оборони В’єтнаму до США.

Найбільш бажаною метою для американських військових був доступ до стратегічно важливої бухти Камран, де в роки В'єтнамської війни знаходилася військовоморська база США, а після війни - СРСР і Росії (до 2002 р.). Це питання піднімалося ще в процесі нормалізації відносин, проте позиція керівництва В’єтнаму була непоступливою. У цілому ставлення Ханоя до розширення співробітництва з США у сфері безпеки залишалося обережним і стриманим. Це пояснювалося передусім глибоко вкоріненою недовірою керівництва В’єтнаму до США.

У 1990-ті рр. «китайський фактор» ще не мав впливу на американсько-в’єтнамські відносини у сфері безпеки, хоча перші пропозиції Е. Лейка про розширення співробітництва були висловлені у 1996 р. після чергової Тайванської кризи. СРВ і КНР нормалізували відносини у $1991 \mathrm{p}$. Дві держави інтенсивно розвивали торговельноекономічні зв'язки; до 2006 р. Китай був найбільшим торговельним партнером В'єтнаму. Також їх поєднувала спільна ідеологія й однопартійні уряди, очолювані Комуністичними партіями. У кінці 1990-х рр. дві держави розмежували свої сухопутні кордони. Проте у них збереглися невирішені територіальні проблеми у Південно-Китайському морі.

Закон КНР 1992 р. про територіальні води і прилеглі до них зони визначав іiї суверенітет над більшістю акваторії Південно-Китайського моря. Це порушувало права В’єтнаму і суперечило положенням Конвенції ООН про закон на морях 1982 р. Економічні реформи в Китаї супроводжувалися модернізацією армії і флоту, що давало підстави прогнозувати відновлення територіальних конфліктів у ПівденноКитайському морі. Проте у 1990-ті рр. це питання ще не набуло гостроти, і у переговорах з США не піднімалося.

Підсумки нормалізації американсько-в’єтнамських відносин підвів чотириденний офіційний візит до В'єтнаму президента Б. Клінтона у листопаді 2000 р. Він був першим президентом США, який відвідав В'єтнам після війни і першим, хто відвідав Ханой. Його супроводжувала велика делегація у складі близько двох тисяч осіб - се-

$3^{8}$ Thayer, C. A.\& Starr, C. V. Op.cit., 26-27.

39 Ibid, 27-28.

40 Embassy of the Socialist Republic of Vietnam in the United States of America. Timeline. Retrieved from http://vietnamembassy-usa.org/vietnam-us-relations/timeline

${ }^{41}$ Lohman, W., Lewis, S. \& Colonel Jordan, W. Op.cit. 
наторів і конгресменів, ветеранів В’єтнамської війни, підприємців. Клінтон провів зустрічі з президентом, прем'єр-міністром, генеральним секретарем Комуністичної партії В’єтнаму, мером і підприємницькими колами міста Хошимін ${ }^{2}$. У Ханої американську делегацію очікував несподівано теплий прийом тисяч в’єтнамців, які вийшли на вулиці їі вітати.

Візит Б. Клінтона розпочався 17 листопада з виступу у В'єтнамському національному університеті в Ханої, який транслювався по національному телебаченню. Спочатку він говорив про тяжкий спадок війни, названій у США «в'єтнамською», а у В’єтнамі - «американською», про її вплив на В’єтнам, США і їхні двосторонні відносини. Далі він підвів підсумки того, що було зроблено після встановлення дипломатичних відносин, і окреслив плани на майбутнє.

Передусім він високо оцінив підписану незадовго до того «історичну» Двосторонню торговельну угоду і відзначив прагнення США надати В’єтнаму технічну допомогу для забезпечення ії повної імплементації43.

США також були готові надавали допомогу В’єтнаму у сфері освіти. В’єтнам вже було включено в одну з найбільших урядових освітніх програм, але США прагнули запропонувати більше. Йшлося про створення нової Фундації освіти В'єтнаму, яка мала підтримувати щорічно 100 освітніх грантів в США і В'єтнамі, а також про готовність США вкласти більше коштів у програми обміну до того часу, поки їі буде створено44.

Водночас Б. Клінтон говорив про важливість необмеженого права використовувати знання, у тому числі, думати, говорити й формувати думки, які збагачують життя людей і націй поза межами економіки, про переваги вільної преси і незалежних судів, про гарантування громадянам прав віросповідання і політичної опозиції. Це, за його словами, не загрожує стабільності суспільства, а навпаки, формує впевненість людей у справедливості державних інституцій і дозволяє приймати рішення влади, 3 якими вони не згодні, а це робить державу сильнішою. Він також прямо заявив, що не намагається нав'язати ці ідеали. «Тільки ви можете вирішити як вплести індивідуальні свободи і права людини в багату і сильну структуру в'єтнамської національної ідентичності» 45 .

США були готові також до посилення співробітництва в гуманітарній сфері (хоча Б. Клінтон не вживав цього терміну): до продовженню роботи по розчищенню мін і снарядів, які не вибухнули, посиленню спільних зусиль для захисту навколишнього середовища від отруйних речовин, постачання чистої води, порятунку коралових рифів і тропічних лісів, попередження і ліквідації наслідків природних лих, включаючи повені в дельті Меконгу. Пропонувалося спільно вивчати вплив діоксину на природу і людей - в’єтнамців і американців, які були у В’єтнамі. Цій меті служила підписана у цей день угода у сфері науки і технологій.

У сфері медицини і охорони здоров'я, за словами Б. Клінтона, США хотіли бути «союзником» В'єтнаму в боротьбі проти смертельних хвороб, таких як СНІД, туберкульоз і малярія. Він обіцяв майже вдвічі збільшити підтримку зусиль В'єтнаму ліквідувати кризу СНІД, надати допомогу у попередженні травмувань на робочих місцях. «Коротко, ми прагнемо будувати наше партнерство з В’єтнамом»46.

Під час візиту значна увага приділялася торговельним питанням. США обіцяли встановити кредитну лінію обсягом 200 млн. дол. для підтримки американських ін-

42 Embassy of the Socialist Republic of Vietnam in the United States of America. (2000, November). President Clinton Welcomed in Vietnam. Retrieved from http://vietnamembassyusa.org/relations/president-clinton-welcomed-vietnam

43 Clinton, W.J. (2002). Remarks at Vietnam National University in Hanoi, Vietnam. November 17, 2000. In W.J. Clinton The Public Papers of the Presidents of the United States. 2000-2001 (in three books). Book 3. October 12, 2000 to January 20, 2001. Washington: United States Government Printing Office, 2550-2551. Retrieved from https://www.govinfo.gov/content/pkg/PPP-2000book3/pdf/PPP-2000-book3-doc-pg2547-2.pdf.

44 Ibid, 2550.

45 Ibid, 2550.

${ }^{46}$ Ibid, 2551. 
вестицій у В’єтнамі. Уряди двох держав погодилися розпочати економічний діалог. Було підписано Меморандум порозуміння з трудових питань щодо безпеки і стандартів на робочих місцях та розвитку навичок робітників, необхідних у новій інформаційній економіці47.

Зустріч Б. Клінтона з Генеральним секретарем Комуністичної партії пройшла, очевидно, невдало. Наступного дня щоденна в'єтнамська газета вмістила статтю, у якій лідер Компартії називав американців «імперіалістами» і висловлював сподівання, що вони будуть поважати інші підходи В’єтнаму до ведення справ ${ }^{48}$.

Б. Клінтон прокоментував цю зустріч в інтерв'ю CNN, а також у своїх мемуарах. За його словами, лідер Компартії Ле Кха Хуеу намагався скористатися його опозицією до війни у молоді роки, щоб засудити іï як «імперіалістичний акт агресії» з боку США. Його «це розлютило», і він «дуже різко відповів», що ті, хто проводив цю політику, не були імперіалістами чи колонізаторами, а гарними людьми, які вірили, що борються проти комунізму. «Ми перегорнули нову сторінку в наших відносинах, нормалізувавши їх... і тепер не час ятрити старі рани»49.

В інтерв’ю CNN 19 листопада він зазначив, що США ніколи не мали ніяких імперіалістичних цілей у В’єтнамі. Війна була конфліктом через те, що насправді означали для в'єтнамського народу самовизначення, свобода і незалежність. Він також висловив сподівання, що реалізація торговельної угоди і вступ до СОТ посилять верховенство права і відкритість В'єтнаму, населення отримає більше доступу до Інтернету й різної інформації, і внаслідок цього - більше свободи. Проте чи стане вона політичною свободою було невідомо5о.

Президент Тран Дук Луонг, за словами Б. Клінтона, «виявився таким самим догматиком» як і Генеральний секретар Компартії51. Натомість 3 прем’єр-міністром Фам Ван Кхаєм у Б. Клінтона склалися гарні відносини ще під час зустрічей на засіданнях ATEC. За його характеристикою, він орієнтувався на майбутнє і сподівався, що США допоможуть В'єтнаму в лікуванні тих, хто постраждав від «Агенту оранж» і в розвитку економіки ${ }^{2}$.

Фам Ван Кхай стане першим прем'єр-міністром, який відвідає США з офіційним візитом у 2005 р.; президент В'єтнаму, на той час Нгуен Мін Чіет, вперше відвідає США у 2007 р.; генеральний секретар Компартії В’єтнаму - в 2015 р.

Під час перебування у В’єтнамі Б. Клінтон відвідав місце, де 33 роки до того відбулося падіння американського літака. Разом з ним прибули два сина загиблого пілота, які разом спостерігали за процесом пошуку. Б. Клінтон писав про цю подію як таку, яку «ніхто з нас ніколи не забуде»53.

47 Clinton, W.J. (2002). Remarks to the Vietnamese Business Community in Ho Chi Minh City, Vietnam, November 19, 2000. In W.J. Clinton The Public Papers of the Presidents of the United States. 2000-2001 (in three books). Book 3. October 12, 2000 to January 20, 2001. Washington: United States Government Printing Office, 2561. Retrieved from https://www.govinfo.gov/content/pkg/PPP-2000-book3/pdf/PPP-200o-book3-doc-pg2561.pdf.

${ }^{48}$ Clinton, W.J. (2002). Interview with John King of CNN in Ho Chi Minh City. November 19, 2000. In W.J. Clinton The Public Papers of the Presidents of the United States. 2000-2001 (in three books). Book 3. October 12, 2000 to January 20, 2001. Washington: United States Government Printing Office, 2563. Retrieved from https://www.govinfo.gov/content/pkg/PPP-200obook3/pdf/PPP-200o-book3-doc-pg2563.pdf

49 Клинтон, Б. (2005). Моя жизнъ. Москва: Альпина бизнес букс, 1040.

${ }^{50}$ Clinton, W.J. Interview with John King of CNN in Ho Chi Minh City. November 19, 2000. In W.J. Clinton The Public Papers of the Presidents of the United States. 2000-2001 (in three books). Book 3. October 12, 2000 to January 20, 2001. Washington: United States Government Printing Office, 2563-2564. Retrieved from https://www.govinfo.gov/content/pkg/PPP-2000book3/pdf/PPP-200o-book3-doc-pg2563.pdf.

${ }^{51}$ Клинтон, Б. Моя жизнь. Москва: Альпина бизнес букс, 1040.

$5^{2}$ Ibid, 1041.

53 Ibid, 1040. 
Усього за період президентства Б. Клінтона в Америку було переправлено близько 300 пакунків з рештками загиблих воїнів. Він наголошував, що прогрес у відносинах з В’єтнамом за останні вісім років був можливим саме завдяки їхньому співробітництву у справі ідентифікації, пошуку і повернення додому МІА. Також він був можливим завдяки підтримці ветеранів у Конгресі (сенаторів Джона Керрі, Боба Керрі, Джона Маккейна, Чака Робба, конгресмена і тогочасного посла Піта Пітерсона) і різних ветеранських організацій 54 . Про це він писав також у своїх мемуарах 55.

У своїх виступах й інтерв’ю Б. Клінтон говорив про «нові» в'єтнамськоамериканські відносини, «нову сторінку в історії», «закінчення в’єтнамської війни». За його словами, війна відділила в’єтнамців від американців, в’єтнамців один від одного. Тріщина у в’єтнамській спільноті розділила також американців. Настав час їі ліквідувати ${ }^{6}$.

Здоланню спадку В'єтнамської війни сприяло те, що близько 6о\% в’єтнамців народилися вже після війни і не пам'ятали їі так, як попереднє покоління. У США візит президента до В’єтнаму також не викликав протесту з боку Національної ліги сімей POW/MIA і ветеранських організацій, які виступали проти нормалізації відносин. У цей час американське суспільство було зосереджене на результатах президентських виборів 2000 р. і спірному голосуванні у Флориді. Це означало втрату попереднього впливу «в'єтнамського синдрому» на американські суспільство і політику.

Таким чином, процес нормалізації американсько-в'єтнамських відносин був досить тривалим. У роки «холодної війни» цьому перешкоджали союзницькі відносини В’єтнаму з СРСР й інтервенція в Камбоджу, а також неготовність до цього американського суспільства. Підгрунтя для нормалізації двосторонніх відносин заклало співробітництво у справі пошуків осіб, які зникли під час В'єтнамської війни, а також зміни, які відбулися у світі, а також у В'єтнамі унаслідок політики ринкових реформ. Після встановлення дипломатичних відносин у липні 1995 р. найбільш важливою подією американсько-в'єтнамських відносин було підписання у липні 2000 р. Двосторонньої торговельної угоди, імплементація якої визначила позитивний напрям їх розвитку в наступний період. Візит президента Б. Клінтона до В’єтнаму у листопаді 2000 р. підвів підсумки цього установчого періоду, основним змістом якого було звільнення двох держав від спадку В'єтнамської війни. Хоч на шляху повної нормалізації відносин залишалися суттєві перешкоди, такі як взаємна недовіра, проблеми права людини і «Агенту оранж» тощо, у 1995-2000 pр. було закладено основи для більш плідного співробітництва двох держав у XXI ст.

\section{REFERENCES}

Albert, E. (2019, March 20). The Evolution of U.S.-Vietnam Ties. Backgrounder. Retrieved from https://www.cfr.org/backgrounder/evolution-us-vietnam-ties [in English]

AP Archive. (1997, June 27). Vietnam: Hanoi: US Secretary of State Madeleine Albright Visit. Retrieved from http://www.aparchive.com/metadata/youtube/c95f1a6c77433a915d659cdd773e86ba [in English].

Baker, J.A. III \& Defrank, T.M. (1995). The Politics of Diplomacy. Revolution, War and Peace, 1989-1992. New York. [in English].

54 Clinton, W.J. Interview with John King of CNN in Ho Chi Minh City. November 19, 2000. In W.J. Clinton The Public Papers of the Presidents of the United States. 2000-2001 (in three books). Book 3. October 12, 2000 to January 20, 2001. Washington: United States Government Printing Office, 2564-2565. Retrieved from https://www.govinfo.gov/content/pkg/PPP-2000book3/pdf/PPP-200o-book3-doc-pg2564.pdf.

55 Клинтон, Б. Моя жизнъ. Москва: Альпина бизнес букс, 746.

${ }^{6}$ Clinton, W.J. Interview with John King of CNN in Ho Chi Minh City. November 19, 2000. In W.J. Clinton The Public Papers of the Presidents of the United States. 2000-2001 (in three books). Book 3. October 12, 2000 to January 20, 2001. Washington: United States Government Printing Office, 2565. Retrieved from https://www.govinfo.gov/content/pkg/PPP-200o-book3/pdf/PPP2000-book3-doc-pg2565.pdf 
Brown, F.Z. (2010, December). Rapprochement between Vietnam and the United States. Contemporary Southeast Asia, 32 (3), 317-342. Retrieved from https://www.jstor.org/stable/25798860 [in English].

Burghardt, R. F. (2006). Old Enemies Become Friends: U.S. and Vietnam. Retrieved from https://www.brookings.edu/opinions/old-enemies-become-friends-u-s-and-vietnam/ [in English].

Christopher, W. (1998). In the Stream of History: Shaping Foreign Policy for a New Era. Stanford, Calif.: Stanford University Press. [in English].

Clason, N.R. (2017). Two Sides on «Normal»: A Comparison of Eight Views on U.S. Rapprochement with Vietnam, 1989-1995. Retrieved from https://d.lib.msu.edu/etd/4593 [in English].

Clinton, W.J. (2002). Interview with John King of CNN in Ho Chi Minh City. November 19, 2000. In W.J. Clinton The Public Papers of the Presidents of the United States. 2000-2001 (in three books). Book 3. October 12, 2000 to January 20, 2001. Washington: United States Government Printing Office, 2563-2569. Retrieved from https://www.govinfo.gov/content/pkg/PPP-200Obook3/pdf/PPP-20oo-book3-doc-pg2563.pdf [in English].

Clinton, B. (2005). Moia zhyzn [My Life]. Moskva: Alpina biznes buks. [in Russian].

Clinton, W.J. (2002). Remarks at Vietnam National University in Hanoi, Vietnam. November 17, 2000. In W.J. Clinton The Public Papers of the Presidents of the United States. 2000-2001 (in three books). Book 3. October 12, 2000 to January 20, 2001. Washington: United States Government Printing Office, 2547-2552. Retrieved from https://www.govinfo.gov/content/pkg/PPP2000-book3/pdf/PPP-200o-book3-doc-pg2547-2.pdf [in English].

Clinton, W.J. (2002). Remarks to the Vietnamese Business Community in Ho Chi Minh City, Vietnam, November 19, 2000. In W.J. Clinton The Public Papers of the Presidents of the United States. 2000-2001 (in three books). Book 3. October 12, 2000 to January 20, 2001. Washington: United States Government Printing Office, 2560-2561. Retrieved from https://www.govinfo.gov/content/pkg/PPP-200o-book3/pdf/PPP-200o-book3-doc-pg2561.pdf [in English].

Embassy of the Socialist Republic of Vietnam in the United States of America. (2000, November). President Clinton Welcomed in Vietnam. Retrieved from http://vietnamembassyusa.org/relations/president-clinton-welcomed-vietnam [in English].

Embassy of the Socialist Republic of Vietnam in the United States of America. Timeline. Retrieved from http://vietnamembassy-usa.org/vietnam-us-relations/timeline [in English].

Gorodnia, N.D. (2014). Skhidna Aziia u zovnishnii politytsi SShA (1989-2013 rr.). [East Asia in the U. S. Foreign Policy, 1989-2013]. Kyiv: Print-servis. [in Ukrainian].

Historical Office. Office of the Secretary of Defense. (1990, March). The National Security Strategy of the United States. The White House, Washington D.C., 9. Retrieved from https://history.defense.gov/Portals/70/Documents/nss/nss1990.pdf?ver=2014-06-25-121138o80 [in English].

Historical Office. Office of the Secretary of Defense. (1994, July). A National Security Strategy of Engagement and Enlargement. The White House, Washington D.C., ii, 2. Retrieved from https://history.defense.gov/Portals/70/Documents/nss/nss1994.pdf?ver=2014-06-25-121219500 [in English].

Lohman, W., Lewis, S. \& Colonel Jordan, W. (2012, July 18.). U.S.-Vietnam Defense Relations: Investing in Strategic Alignment. Retrieved from https://www.heritage.org/ asia/report/us-vietnam-defense-relations-investing-strategic-alignment [in English].

MIA Affairs United States Senate. (1993, January 13). Senate Report 103-1 POW / MIA'S Report of the Select Committee on POW. Retrieved from https://fas.org/irp/congress/1993_rpt/powexec.html [in English].

Ministry of Foreign Affairs. (2005, June 23). Trade Agreement with the US is Good Beginning to Vietnam's WTO Bid. Retrieved from http://www.mofa.gov.vn/en/nro40807104143/ nro40807105001/ns050621101212/view [in English].

Ministry of Foreign Affairs. (2007, July 2). Vietnam-US Relations Outlook. Retrieved from http://www.mofa.gov.vn/en/cn_vakv/america/nro40819114015/ns041111092523/view [in English].

Ministry of Foreign Affairs. (2007, November 29). US to Increase Scholarship Funds for Vietnam: US Ambassador. Retrieved from http://www.mofa.gov.vn/en/cn_vakv/america/nro40819114015/ns071129092940/view [in English].

Ministry of Foreign Affairs. (2010, June 29). Vietnam-US Ties Boosted by Trust Building Efforts. Retrieved from http://www.mofa.gov.vn/en/nr040807104143/nro40807105001/ns100630150512/view [in English].

Ministry of Foreign Affairs. (2019, June 13). Viet Nam-U.S. Relations. Retrieved from http://www.mofa.gov.vn/en/cn_vakv/america/nro40819114015/nso71015155903 [in English]. 
Pidbereznyh, I.E. (2012). Rozvytok vidnosyn miz SShA i Vietnamon: Suchasnyi stan, napriamky, perspectyvy. [Development of relations between the US and Vietnam: current status, trends and prospects]. Naukovi pratsi istorychnoho fakultetu Zaporizkoho natsionalnoho universytetu, $X X X I V, 242-247$ [in Ukrainian].

Shenon P. (1995, August 5). Bush is Criticized for Plans to Speak in Vietnam. The New York Times. Retrieved from https://www.nytimes.com/1995/o8/05/world/bush-is-criticized-for-plans-tospeak-in-vietnam.html [in English].

Shoji, T. (2018). Vietnam's Security Cooperation with the United States: Historical Background, Present and Future Outlook. Retrieved from http://www.nids.mod.go.jp/english/publication /kiyo/pdf/2018/bulletin_e2018_2.pdf [in English].

Thayer, C.A. \& Starr, C.V. (2005). The Prospects for Strategic Dialogue. Dialogue on U.S.Vietnam Relations. Ten Years after Normalization, 3. San Francisco: The Asia Foundation. Retrieved from https://asiafoundation.org/resources/pdfs/1-VN1oYearsAfterNormalization.pdf [in English].

The Avalon Project. Documents in Law, History and Diplomacy. (1989, January 20). Inaugural Address of George Bush. Retrieved from https://avalon.law.yale.edu/2oth_century/bush.asp [in English].

The University of Edinburgh. Peace Agreements Database. Final Act of the Paris Conference on Cambodia. Retrieved from: https://www.peaceagreements.org/view/378 [in English].

United States. Congress. Senate. Committee on Foreign Relations. (1995). Congressional Delegation Trip Report: Countries Visited: Mongolia, People's Republic of China, North Korea, South Korea, and Vietnam, December 3-17, 1994: a report to the Committee on Foreign Relations, United States Senate by Frank H. Murkowski and Paul Simon. Washington: U.S. G.P.O., 13-15. Retrieved from https://babel.hathitrust.org/cgi/pt?id=pst.o00023494220\&view=1up\&seq=3 [in English].

U.S. Congressman Chris Smith. (1996). Human Rights in Vietnam. Joint Hearing before the Subcommittees on Asia and the Pacific and International Operations and Human Rights of the Committee on International Relations House of Representatives. One Hundred Fourth Congress. First Session. November 8, 1995. Washington D. C.: U. S. Government Printing Office. Retrieved from https://chrissmith.house.gov/uploadedfiles/1995.11.08_human_rights_in_vietnam.pdf [in English].

U.S. Embassy and Consulate in Vietnam. Bilateral Trade Agreement. Retrieved from https://vn.usembassy.gov/our-relationship/policy-history/bilateral-trade-agreement/ [in English].

U.S. to Open an M.I.A. Office in Hanoi (1991, April 21). The New York Times. Retrieved from https://www.nytimes.com/1991/04/21/world/us-to-open-an-mia-office-in-hanoi.html [in English].

Vuving, A. (2017, May 27). What Vietnam Can Offer America. The National Interest. Retrieved from https://nationalinterest.org/feature/what-vietnam-can-offer-america-20874?page $=5$ [in English].

Nataliya Gorodnia,

Taras Shevchenko National University of Kyiv, Kyiv, Ukraine ORCID: https://orcid.org/oooo-ooo1-8152-3927

Inna Pidbereznykh,

Petro Mohyla Black Sea National University, Mykolaiv, Ukraine ORCID: https://orcid.org/oooo-ooo1-9906-4327

\section{Normalization and Development of the United States-Vietnam's Relations in $1990 \mathrm{~s}$}

The authors study the normalization of the U.S.-Vietnam's relations under G. H.W. Bush and W. Clinton administrations, the factors that influenced the process, and the major events and spheres of American-Vietnamese interactions after the normalization, in 1995-2000. The developments are studied in a chronological order at the background of shifts in the U.S. and Vietnam's politics, and transformations in the international system. The research is based on a study of primary sources, including materials of the U.S. Department of State, the Ministry of Foreign Affairs of Vietnam and Vietnam's Embassy in the United States; remarks, interviews and publications of the U.S. Presi- 
dents, Secretaries of State, diplomats, Congress reports, bilateral and multilateral agreements, media news, et cetera.

The paper reveals that the major theme of the normalization process was two nations' cooperation in the POW/MIA issue. The normalization was not a high priority of G. H. W. Bush and W. Clinton's administrations for many reasons, including reluctance of American society. However, it was promoted by some influential groups in the U.S., including Senators and Congressmen who were the veterans of the Vietnam War, and the American corporations, which were seeking for new economic opportunities. Establishment of diplomatic relations with Vietnam in July 1995 was one of the hardest President Clinton's decisions. The driving force of the U.S.-Vietnam's relations after normalization was the Bilateral Trade Agreement, signed in July 20oo. However, mutual distrust, human rights issue and many other inherited from the Vietnam War issues hampered the progress in other spheres. The President Clinton's visit to Vietnam in November 2000 summed up 1995-200o introductory period of the bilateral relations, the most important result of which was freeing both nations' politics from the negative impact of the Vietnam War.

Key words: U.S.-Vietnam's relations, United States' foreign policy, Vietnam's foreign policy, G. H. W. Bush administration, W. Clinton administration 